\title{
Paperless and Jobless: The Undocumented Status and Access to Employment among Latino Youth
}

\author{
ELŻBIETA M. GOŹDZIAK' \\ Adam Mickiewicz University in Poznań \\ JOSEPH RUSSELL-JENKINS \\ Georgetown University
}

This paper is based on a study on the effects of unauthorized migration on Latino children and youth's access to education, healthcare, and livelihoods. The research project aimed at improving understanding of the many nuanced effects of undocumented status on employment and livelihood prospects of Latino youth. Research involved ethnographic fieldwork in three neighborhoods in the larger Washington, DC metropolitan area: Chirilagua, VA, a neighborhood on the border of Alexandria and Arlington in northern Virginia; Langley Park, MD; and Columbia Heights, in DC. In this article we attempt to explore the circumstances faced by Latino youth as they transition into adulthood and analyze the effects of unauthorized status of the young person or other family members on incentives to work and access to the labor market. We argue that while these youth are often pressured to choose waged employment over education in order to contribute to the family's income, their lack of legal immigration status is an incentive to stay in school for the relatively safe legal environment it affords. Once the decision to work has been made, or graduation from high school has forced them out of the safety net, the limited options for work available to these youth create difficult decisions wherein some seek work in safe environments for less compensation while others choose more formal, higher-paying positions that come with exposure and high risk.

Keywords: international migration, Latino youth, livelihoods, employment

\section{Introduction}

In the United States, the public discourse on immigration often gravitates toward the subject of unauthorized immigrants. Approximately one-fourth of all immigrants in the US are unauthorized (Suárez-Orozco et al., 2011), and yet this group attracts

1 Corresponding author: Elżbieta Goździak, emg27@georgetown.edu 
the majority of political and media attention. A large body of literature has examined the lives of unauthorized workers in the US labor force (e.g. Massey, 1987; Massey et al., 2002; Hall et al., 2010). Much less is known about unauthorized migrant children and US citizen children living with unauthorized parents, though some research on this group has emerged (e.g. Abrego, 2006; Martínez, 2009; Yoshikawa, 2011; Gonzales, 2011; Suárez-Orozco el al., 2011). While these young people are difficult to access and typically do not show up in survey data, it seems clear that they do not follow the conventional patterns of the second-generation immigrants who constitute much of their peer group (Gonzales, 2011).

There are approximately one million unauthorized children and young people growing up in the United States and more than four million children who have American citizenship but have at least one unauthorized parent (Passel and Cohn, 2010). In total, one in every ten children in the country lives in a mixed-status family (Passel, 2006) and children of undocumented parents make up approximately seven percent of school-age children (Passel and Cohn, 2010; Passel and Taylor, 2010). The federal Development, Relief, and Education for Alien Minors (DREAM) Act has drawn attention to this subpopulation. Introduced and debated repeatedly in Congress since 2001, the legislation is intended to assist unauthorized students in obtaining in-state tuition at public universities and offers a path to legal residency for young people meeting certain criteria. However, it has languished without success (Migration Policy Institute, 2010; Olivas, 2010). Recently, attention has been refocused on the DREAM Act by the Trump administration, which tried to abolish the executive order of the Obama Administration issued in 2012 and known as Deferred Action for Childhood Arrivals (DACA). The latter grants a temporary (two-year) legal status and work permit to young unauthorized immigrants who meet similar criteria.

This essay is part of a larger study on the role unauthorized status plays in Latino children and youths' access to education, healthcare, and livelihoods and aims at improving understanding of the many nuanced effects of undocumented status on employment and livelihood prospects of Latino youths. Research involved one year of ongoing ethnographic fieldwork, carried out between 2010 and 2012, in three neighborhoods in the larger Washington, DC metropolitan area: Chirilagua, VA, a neighborhood on the border of Alexandria and Arlington in northern Virginia; Langley Park, MD; and Columbia Heights, in DC. The study was conducted to inform the immigration debates taking place in the United States at the time and the findings emerged organically from the ethnographic methodology focused on the insiders' points of view.

We conducted a total of 27 individual interviews with children and young adults (14 males and 13 females) and one group discussion with eight young adults (two women and six men). The respondents ranged in age from 12 to 22 years old; the majority of the young people were between 15 and 19 years of age. While we did not ask directly about our interviewees' immigration status, virtually all participants 


\section{SM̂PP}

volunteered this information. Immigration status has impacted their educational and employment pursuits so profoundly that a meaningful discussion about access to opportunities was not possible without mentioning one's immigration status. Ten of the interviewed children were citizens, born in the United States but living in largely undocumented households. One young person had a Temporary Protective Status (TPS), while the remaining of the non-citizen children were unauthorized. None of the young people in this study had DACA as the study ended just at the time when President Obama signed the executive order. ${ }^{2}$ The interviewees came from El Salvador, Guatemala, Honduras, Mexico, Bolivia, and Colombia. In addition, we interviewed 17 parents (13 mothers and four fathers); six parents were interviewed individually and 11 parents participated in two different group discussions. Five of the parents lived in a household where all members were undocumented; two were part of documented households, while six lived in mixed-status households. Four of the interviewed parents did not disclose their immigration status.

Due to the difficulties of identifying working Latino youth directly through employers--who tend to be very hesitant to grant access to their workers-we relied heavily on community-based organizations, including day labor centers, and wordof-mouth, in our pursuit of finding working adolescents and young adults willing to be interviewed. There are relatively few programs in the DC metro area that focus specifically on employment for immigrant youth, however, many advocates as well as other stakeholders had much to say about Latino youth's access to employment, poverty of Latino families, and prospects for decent livelihoods. We interviewed 15 stakeholders, including government officials in the Office of Latino Affairs (OLA) in the District of Columbia; officials in the DC Public Schools; administrators and teachers in two different charter schools; school social workers; case managers working with low-income families; a program manager at a youth center; and a couple of programs employing immigrant youth as part of the DC Summer Youth Jobs. We also conducted participant observation of community meetings, including a Latino Youth Town Hall organized by OLA; and a focus group discussion on neighborhood safety facilitated by youth from the Latin American Youth Center (LAYC).

In this essay, we attempt to explore the circumstances faced by Latino youth in the Washington, DC metropolitan area as they transition into adulthood and analyze the effects of unauthorized status of the young person or other family members on incentives to work and access to the labor market. We argue that while these young people are often pressured to choose waged employment over education in order to contribute to the family's income, their lack of legal immigration status is an incentive to stay in school for the relatively safe legal environment it affords. It is important to remember that school-age children have access to public education

2 DACA, an executive branch memorandum, was announced by President Barack Obama on June 15, 2012. U.S. Citizenship and Immigration Services (USCIS) began accepting applications for the program on August 15, 2012. Our study ended in September 2012. 
from Kindergarten to grade 12 regardless of their immigration status. Moreover, requiring students or their parents to provide schools with information regarding their immigration status violates the constitutional principles set out in the US Supreme Court case Plyler v. Doe, 1982. Once the decision to work has been made, or graduation from high school has forced them out of the safety net (see Gonzales, 2011), the limited options for work available to unauthorized youth create difficult decisions wherein some seek work in safe environments for less compensation while others choose more formal, higher-paying positions that come with exposure and high risk. Whichever direction these young people decide to go, it is clear that the social networks (O'Regan and Quigley, 1993; Wilson, 1987) and positive mediators (Gonzales, 2011) that are much hailed in the urban poverty and youth development literature, respectively, are important in the context of their unauthorized status.

\section{The Decision to Work or to Stay in School: Facing Conflicting Motivations}

For many young people from immigrant families, poverty and financial hardship are facts of life (Crowley, 2006). In these poor and working-class environments, the labor contribution of children and youth is often crucial for the family's survival, in the United States just as in their country of origin (Berrol, 1995; Song, 1999). Furthermore, Bachmeier and Bean (2011) have described the role of labor force participation for Mexican youth as it relates to the decision to drop out of high school, arguing that a strong draw to the labor force is partially a result of cultural factors inherent to working class migrant groups. In the case of unauthorized youth, these forces also create a pull toward the labor force and away from school. However, for the younger teens, the final calculus may be altered due to their limited access to the labor market. Our research suggests that while unauthorized youth often faces pressures to work that are consistent with their family's economically disadvantaged status, many end up eschewing work in favor of concentrating on school because the latter provides a safer environment. Many worksites are prone to immigration raids and may result in deportations, while immigration authorities are not allowed to enter schools.

We expected that most of the Latino youth in the Washington DC metropolitan area, even those that attended school, would be working, either to support their family, themselves, or to pay for various expenses. As Gonzales (2011: 605) suggests, "Many of the 1.5 and second generations of certain immigrant groups are in reciprocal financial relationships with their parents, often even supporting them." In reality, however, few of the young people we interviewed in the course of this research were working.

At first, we assumed that we were not finding working youth, because our access to worksites was limited. We also hypothesized that adolescents connected to 


\section{SM̂PP}

community-based organizations and youth programs may be inherently less likely to be in the workforce and out of school than young people without such connections. The children and adolescents who attended school did hold summer jobs, but did not work during the school year, except for helping in the family businesses - mainly restaurants and stores. They also took care of younger siblings while their parents held multiple jobs. Some adolescents were desperate for paid employment but were having hard time finding jobs.

Alejandro was taking evening courses at a community college in Maryland but wanted to work during the day to help out his mother and to have pocket money to buy his baby brother presents. He searched high and low to no avail. He even contemplated changing his course schedule to accommodate the possibility of working night shifts at a neighborhood restaurant, but in the end the restaurant hired someone who "had papers." It took Alejandro several months to land a job as a receptionist at a non-profit organization. He was paid in cash under the table.

Pedro told us that whenever he approached construction managers along the 14th Street corridor in Washington, DC, for a job, even a day job, he was asked if his father was looking for work. Construction work was plentiful in Columbia Heights, he said, but employers were looking for adult men with experience in hanging drywall or painting, not youngsters eager to work but with fewer vocational skills. Employers at fast food eateries or big box stores we talked to indicated that local youth - both immigrant Latino and native African American young people were competing for jobs with adults who were laid off from work as a result of the economic downturn. The economic situation in the United States has much improved since the time of our study. However, while the current national unemployment rate is $3.7 \%$, a significant decrease since the 2012 unemployment rate of $9.0 \%$, the unemployment rate in the DC metropolitan area still hovers around $5.6 \%$. Many also speculate that increased immigration enforcement might further limit employment opportunities for immigrants, youngsters and adults alike. No empirical research with local youth has been conducted, so the speculations remain mere hypotheses.

\section{Financial Pressures: Some Common, Some Not}

For those that do work, as with other immigrant Latino youth in the US, labor roles actually differ from those in their countries of origin, affecting how children grow up here, as a key stakeholder in our interviews pointed out. In their countries of origin, these same children would merely help with chores and domestic work, whereas here they are expected to contribute to the family's income, which typically involves work outside the home. Therefore, in spite of legal barriers to labor market access, these young people have to find some way to aid in supporting the family. 
Outside of family obligations, some children and youth that we interviewed had to work in order to support themselves. Jesus, for example, came to the US by himself when he was 13 years old and worked in order to pay for his own rent and food while in school. He continued to be entirely financially and socially independent until his schoolteachers realized his situation and he was put in foster care at age 17. More often, unauthorized children who have to be financially self-sufficient do not attend school at all. Instead, they function as independent adults even before they reach the age of 18 . This group is typically composed of older adolescents and young adults who come to the United States in their late teens, usually after years of being separated from their parents, and never "drop in" to a school in the US. Instead they enter the labor market immediately to repay the money that their family paid a coyote (a smuggler who brings someone illegally across the border and - optionally - to the destination city). The family often pays up front and then the young person spends years paying off his or her debt to the family. For this group, the need to work is a burden that limits their freedom and brings them stress of adult life at an earlier stage.

Jose, an 18-year old day laborer interviewed in DC had been working in the US for four years and lived with his brother. The siblings supported each other and sent money back home to Guatemala when they could. While some self-supporting youths are also assisting their families through remittances, these cases are rare since the primary focus for these young people must be on paying their own expenses in the US, or settling coyote debts, with what little they earn. Josefina, a teen mom, dropped out of school in 10th grade and when we first met her worked as a server in a restaurant to support herself and her baby. Her daughter's father was in and out of the picture and she could not rely on him. She was also studying English because she wanted to move up and become a hostess in a more upscale restaurant. She regretted her decision to drop out of school, but there were few alternatives for her since she did not have anybody to help her care for her child.

Some youth respondents also work to pay for particular expenses but can depend on family support in other areas. Often, for example, they are responsible for their educational expenses. Some interviewees had to work to pay for their college education or pay off student loans because their families either could not afford it or did not want to support their education. Jamie's mother, for example, has the financial means to contribute to her children's education. She owns several businesses - a restaurant, a pool hall, and a beauty salon--and is doing quite well. However, she will not contribute to college tuition. Without family contribution to his college expenses, Jamie dropped out of college in his senior year and has been working as a sous chef in a French restaurant to pay back his college loans.

US-born Latino youth living in unauthorized families struggled with the same challenges as other, poor young people who are US-citizens. However, these challenges were much more daunting for unauthorized youth because they have less 


\section{SM̂PP}

access to financial aid than their citizen peers, and thus typically face a much greater financial burden in attending college. As indicated above, the particular expense unique to unauthorized youth is the common need to pay the family back for coyote fees. This expense can create tension in a family environment. One interviewee talked about the need to pay his mother back for the coyote fees and how this obligation and the fights that ensued because of it made him feel abandoned by his mother. Although not all unauthorized young migrants are responsible for paying these fees, many do have to contribute. At the time of our study, migrants paid approximately $\$ 3,000$ to coyotes to be smuggled from Mexico, while Central Americans (who are the main Latino population in the DC area) paid upwards of $\$ 6,000$.

\section{Unauthorized Status as a Pull toward School}

Yet, as noted, many of the youth we interviewed did not work, and our research suggests that their unauthorized status was often a mitigating factor for the attraction to work. Some simply found their legal status to be too strong a barrier to employment, in spite of the fact that their parents work for cash or with forged papers. Fernando said that he had always wanted to work when growing up but that he had been unable to find jobs due to his legal status, and so had dedicated himself to academics instead. Analisa said that her father forbade her from working because he did not want her to forge documents. He wanted his children to follow the law as best they could, she said, in spite of the fact that they are unauthorized. Her father's prohibition was frustrating to her and she spoke about her hope of working, at least in the summers, and how her father's employer (a foreman at a metal recycling company) could help her find work. However, Analisa's biggest aggravation was how her peers who did work viewed her. She said, "People think I am a pampered princess because I am not working and my dad is paying for everything. But it isn't that I don't want to work!" Thus, it appears that parental pressure is far from a unidirectional force pushing children to contribute to the family income. In fact, parents often respond to the legal employment barriers by wanting their kids to focus on education and be protected while in school.

In some cases, even if the children had legal status they would not work during school, such as one interviewee, Flora, who said that even if she could legally work she did not think she would. While such decisions may simply be a symptom of the financial freedom afforded to youth whose parents have been especially successful in the labor market, some scholars have suggested that working-class Latino immigrant families possess what they call a "cultural repertoire" that emphasizes distinctive orientations to school and work engagement and discourages the participation of adolescents in both simultaneously (see Van Hook and Bean, 2009; and Bachmeier and Bean, 2011). This theory suggests that, whereas for many Latino youth there is 
a natural attraction to join the workforce, for those unauthorized youngsters who show success in school, cultural factors may cause added pressure from the family to focus solely on school.

\section{An Awareness of Future Exclusion}

Whatever the reason for focusing on school, most unauthorized youth will eventually face the same harsh realities upon completion of high school. Although several states $^{3}$ have passed the DREAM Act allowing undocumented students to pay in-state tuition, many immigrant families are not able to afford college. This means that a vast majority of unauthorized young migrants will be forced to enter the labor market and thus face what Gonzalez (2011) has likened to a rude awakening. These youngsters must "learn to be illegal" as they suddenly transition from the protected environment of school - where they enjoy a de facto legal status - to the complete exposure and vulnerability of adult life. In his research, Gonzalez describes this transition for unauthorized youth whose legal status was either unknown to them until they graduated from high school or who did not fully realize the difficulties it would present. He specifies that young people faced severe disillusionment as the realities of trying to pursue their aspirations with unauthorized status set in.

Yet, in our research we found that many young unauthorized students were already fully cognizant of the difficulties they would face after graduation. This knowledge was attributed to advocacy efforts launched by a variety of local communitybased organizations aimed at educating Latino youth about rights and vulnerabilities. Indeed, many who were still in school already expressed a sense of hopelessness at their future job prospects. For example, one young woman, Maria, talked about wanting to become a math teacher, but said she has no idea how she will ever achieve that after graduation. One parent spoke of his 16-year-old stepson who was generally withdrawn and unmotivated because he was certain he could not find work without a Social Security Number. Two other young men, Francisco and Luis, both said they had even considered going back to Mexico and from there seeking employment in another country. But, said Francisco, "As graduation approaches, I realize that I don't want to leave the US." His immediate family lived in the area and he had many other relatives around the country. All of his friends were in the US as well, so Francisco was not willing to lose his familiar and peer networks.

\footnotetext{
3 At the time of this study, California, Colorado, Connecticut, Florida, Illinois, Kansas, Maryland, Minnesota, Nebraska, New Jersey, New Mexico, New York, Oklahoma, Oregon, Rhode Island, Texas, Utah, and Washington passed the Dream Act that allowed undocumented students who attended and graduated from the state's primary and secondary schools to pay the same college tuition as citizen students.
} 


\section{SM̂PP}

\section{Obtaining Employment: The Risk of Exposure}

Once unauthorized youth do make the decision to work or graduate from high school and are compelled to seek employment, they face resource-barriers due to their inability to work legally. Most feel the frustration of being forced into low-wage jobs or having to work informally alongside their parents (Gonzales, 2011). Some find waged employment where they are paid in cash, while others obtain forged documents in order to work, a process they often do not fully understand. Those who do work for cash may do so for seemingly benevolent employers, but some may also face exploitation and legal risks in the workplace.

The literature on urban poverty has long emphasized the important role of household members in providing access to jobs for young family members ( $O$ 'Regan and Quigley, 1993; Wilson, 1987). The inability of unauthorized youth to apply for most job openings makes their reliance on family and friends doubly important. Indeed, many undocumented young adults work informally, alongside their parents, rather than finding waged employment. Several mothers who cleaned houses or office buildings would bring their adolescent children to help out. "My daughter works very fast and my son can carry heavy things," said one mother, "with their help I can clean twice as many houses in the same time and make more money." This informal arrangement is often for the sake of augmenting the earning potential of a family member, rather than earning an independent wage. For example, starting at age 10, Cata would help her mom clean apartments during breaks from school. She would work from noon to midnight or later, but not earn any money. It was simply a manner of supporting the family without putting herself in the legal risk of needing to forge paperwork as it would have been the case if she wanted to work in retail or in a restaurant.

Cata's situation is also a reflection of the gendered difference in employment of unauthorized youth. Girls tend to work alongside their parents or work unofficially in the home whereas boys tend to have more official, waged employment. The work that girls do inside the home is often not considered employment but is just as critical to supporting the family and ensuring that the parents can maximize their work hours and therefore their incomes. Often, parents who do not want their children working illegally, see this work inside the home as another way for their children to contribute to family life without running the risks of unauthorized employment.

\section{Employers: Benevolence of Exploitation}

Many unauthorized youngsters do find illegal, waged employment from a variety of sources, either through informal connections or with forged paperwork. Some interviewees talked about jobs that never required them to show paperwork. These 
opportunities most often came through friends or community connections. In the case of Marta, she obtained employment as a cashier in a local bakery via the recommendation of a friend from her church and the employer did not require her to complete much in the way of paperwork. As indicated above, Alejandro worked as a receptionist in a small non-profit and was paid in cash. He had looked for some time for waged employment with no success before a community leader connected him with the job. Another young man, Francisco, had also worked in several places at his university thanks to connections with university officials who helped him obtain employment without requiring legal documentation. Employers in each of these cases had some idea that their employees did not have the immigration status to work legally but were willing to overlook this barrier due to personal connections. Further, the employers also often ignored immigration status due to the altruistic desire to help young people access better opportunities and financial resources.

However, while these employers could be considered "benevolent" in the sense that they offer employment to young people without paperwork, such jobs can also leave unauthorized youth vulnerable to various forms of exploitation. This is the case for youngsters who work as day laborers and are paid in cash at the end of the day. In such cases, workers often suffer wage theft in which they will complete a day's work and the employer will refuse to pay, knowing that the laborers will not use legal recourse to obtain their wages. In fact, even with the appropriate legal channels, it is difficult for day laborers to recover the wages they have earned. Another class of employers that do not require legal documentation are those who offer very low-paying jobs. As one interviewee said of the DC-area restaurants, "they don't pay enough money to require paperwork. "According to the interviewees, these jobs are not necessarily below minimum wage, but they seem to be below what authorized workers will accept in compensation. Therefore, such jobs are economically exploitative of the unauthorized status and serve to distort the labor market.

\section{False Documentation: Stepping into Murky and Dangerous Waters}

Most employers do, of course, require legal documentation and some unauthorized youth obtain false documentation in order to work. Typically, these young people are not aware of exactly how such documentation has been acquired or processed. One interviewee, Fernando, said that he simply paid someone that another immigrant had recommended. That person then filled out the employment forms for him and Fernando submitted them. With these forms, he was able to work at a sandwich shop and later at a restaurant. Another young person said that his aunt and uncle had taken care of the forms and he was unsure of how he overcame the legal barrier to employment. In these cases of false documentation, the youth in these interviews 


\section{SM̂PP}

did not appear to be coy or unwilling to reveal the process they had undergone, only that they were not aware of the intricacies of obtaining false documentation and that someone else had taken care of the process for them.

Yet, whether they are fully cognizant of the decision or not, working with false documentation clearly involves exposure to serious legal risks for these young people. Suárez-Orozco and colleagues describe this process as crossing a threshold from a passive and innocent childhood into an adulthood that, for them, requires sudden criminality: "Once they dip their toes into the underground waters of false driver's licenses and Social Security Numbers, they are at risk of getting caught in the undertow of a vast and unforgiving ocean of complex legal currents" (Suárez- Orozco et al., 2011: 455). Most of the youngsters in our study, especially the older ones, understood very well that they were breaking the law working or simply living in the United States "sin papeles." However, short of self-deporting, they and their families had no other choice.

\section{Innovation Happens but Struggle is the Norm}

Beyond the more typical channels for securing employment discussed above, there are some highly innovative unauthorized young people who, through their own initiative, sell products and create side-businesses. Often, these enterprises are insufficient in and of themselves to financially support the youth, but they do help with the overall expenses. One interviewee had begun a truffle reselling business. Another produced works of art when not working his job, which he would sell either on special requests or simply on the street. Such entrepreneurship is a sign of the creativity and determination of many unauthorized youngsters who look for different ways to earn a living in spite of legal barriers. Yet, these instances were rare among our interviewees.

Moreover, these and other successes reported here should not distract from the reality faced by unauthorized youth as they are simply unable to find steady work due to their immigration status. Some may find small side jobs that are insufficient to generate the income that they need. One interviewee, Alejandro, obtained his GED but reported that he was unable to find steady employment because everywhere he looked required a Social Security Number. He made a small amount of money by babysitting and other odd jobs but was frustrated by his inability to contribute to his family's income. Rafael also reported that it was difficult to find an employer without a Social Security Number. Employment difficulties had already forced his family to move to Texas where his uncle had jobs lined up for most of them. These stories are more the rule than the exception for unauthorized youth.

Some community and advocacy organizations found creative ways to compensate undocumented youth for on-the-job training. One organization in Washington DC secured a grant from the DC Council to place immigrant youngsters as counselors at a summer camp for at-risk youth. The migrants worked alongside other counselors 
who were employed through the DC Summer Youth Employment program but were given educational stipends as opposed to wages. The youngsters and their families were very appreciative of the opportunity to participate in this creative program.

Several service providers, community advocates, and local employers suggested that the economic crisis has adversely affected immigrant youth as they compete for jobs with adult immigrants, often their own parents. One interviewee who arrived in the US in 2007 reported seeing the effects of the economic crisis in drastically reduced employment opportunities soon after he arrived. The American dream of endless employment opportunities was no longer true and he has found life here much more of a struggle than he had thought it would be. A couple of employers in retail stores indicated that they prefer US-born college students to fill seasonal positions during the winter holiday season. Sometimes their preference for college students stemmed from their preconceived notions that Latino youngsters do not speak English, are illiterate, and do not have good people skills. "Why would I want some country hick who barely speaks English when I can have a college kid from Georgetown or GW [George Washington]," said one store manager. It is difficult to distinguish between increased employer-based immigration enforcement under the Obama administration, the economic crisis that diminished job opportunities in general, and discrimination against Latino youth.

\section{Education and Future Job Prospects: Falling Flat}

The legal status of unauthorized youth affects their ability to find waged employment and gain meaningful work experience. Yet, as a growing body of literature has established, it also has deleterious effects on education outcomes. The DREAM Act has focused attention on the fact that unauthorized youth cannot access in-state tuition and other financial aid in most states, and thus face substantial barriers to pursuing higher education. But evidence is also mounting that unauthorized status, whether of the children themselves or their parents, harms students' performance in high school (Bean et al., 2011; Bean et al., 2012; Olivas, 2011; Haskins and Tienda, 2011; Gonzales, 2011). Nationwide, 40 percent of unauthorized young people, ages 18 to 24, have not completed high school. Those who entered the US before age 14 have fared somewhat better, with 72 percent having completed high school (Passel and Cohn, 2009).

Reasons for the underperformance of unauthorized students and US citizen children of unauthorized parents are numerous and complex. Broadly, they include lack of positive parental involvement, the stress of unauthorized status, family pressures to work, and possibly ethno-racial discrimination. I have published findings stemming from this study regarding education of unauthorized children (Goździak, 2014; see also Gonzales, 2011; Bean et al., 2012). This research suggests that sending of remittances is highly correlated with children not completing high school. 


\section{SM̂PP}

Whatever the causes of high school drop-out rates among this youth, the result is diminished opportunities for upward mobility. A commonality across most of the youth we interviewed was that career and employment aspirations were typically rationalized in reference to the jobs of the parents. The desire to earn more than their parents did was a primary motivation for most of these young people. Indeed, many parents also expressed the desire for their children to surpass their own economic status, and, as one mother phrased it, "become someone." However, she and others had few concrete ideas on how to achieve this or what this scenario would look like. For those who do not graduate from high school, the lack of high school diploma will compound their troubles in a labor market where their legal status may already be a substantial barrier.

For those who do complete high school, there is often an intense disillusionment that occurs when they realize that they do not have access to jobs beyond the restaurants and cleaning services in which their parents work. For them, "The assumed link between educational attainment and material and psychological outcomes after school is broken" (Gonzales, 2011) as they find themselves stuck in industries where employment has often expanded but wages have stagnated or fallen in the US over the past three decades (Goździak 2010). Those who arrive later in adolescence may never integrate into the school system at all. One young man from Honduras, who arrived four months prior, expressed his intention to eventually return to school but admitted he had no idea how to even go about this process or who he could turn to for help. For this group, a lack of upward mobility is less of a ceiling and more of a wall. And for all of these young people, the result is "not emerging, but (sub) merging adulthood" (Suarez-Orozco et al., 2011) in which, despite their aspirations, the dual effects of stunted education and a lack productive work experience puts this generation at risk of remaining at the same economic level as their parents.

\section{Conclusion}

For unauthorized youth and children of unauthorized parents living in the United States, the financial burden of poverty, as well as a possible working-class cultural repertoire, create pressures to find work, much as they do for other first and second-generation immigrants. Unauthorized youth may also face unique financial burdens due to family debts incurred during the process of migration. Yet, in contrast to what these pressures would suggest, our research indicates that the safety net, or "de facto legal status" (Gonzales, 2011) of K-12 education mitigates the attraction to work for school-aged youth, and in some cases, may be the deciding factor that keeps them out of the labor force.

Prior research has documented the difficult transition from school into the labor force for unauthorized youth, which may be like a nightmare as they suddenly realize 
their legal status (see Gonzales, 2011; Suarez-Orozco, 2011). Yet, the unauthorized young people that we interviewed throughout our research showed a general awareness of the difficulties awaiting them in jobs and careers. For some, their sentiments bordered on despair about the future.

Indeed, the experiences of those already in the labor force bore out these fears. Difficult decisions are often confronted by the young people, especially as they choose between informal employment that may offer protection but lower wages, on the one hand, and the risk of exploitation, and formal employment using falsified documents, on the other hand. For those who choose the latter, or have it chosen for them, they may find themselves being pushed by their unauthorized status into illegal behavior in a way that few appear to understand fully.

Our research also suggests that there is a certain subset of young people in this group that never entered the "inclusion" and "integration" of the public school system (Gonzales, 2011) and for whom unauthorized status has been a reality from the very beginning. For this group, the challenges of their status may be unique to both youth enrolled in school and to unauthorized adults with whom they may compete in the job market. As to how the prospects and work trajectories of this subset look different, if at all, is a compelling area for future research.

As the Trump administration is focused on increased deportations of undocumented immigrants, the situation of children and youth is becoming even more dire. Immigrant parents of the US-citizen children are putting safeguards in place to ensure that their children are protected if they themselves get deported. In the antiimmigrant atmosphere, so prevalent in the United States these days, the unauthorized status of young people has a detrimental effect on the job prospects of youth for whom the typical financial pressures of being from low-income families have already pushed them into the labor force. A common goal among all these young people is to achieve greater career and financial success than their parents. But, for most, that dream seems unlikely to be realized.

\section{References}

Abrego, Leisy J. (2006), I Can't Go to College Because I Don't Have Papers: Incorporation Patterns of Latino Undocumented Youth. "Latino Studies", 4: 212-231.

Autor, D. (2010), The Polarization of Job Opportunities in the US Labor Market: Implications for Employment and Earnings. Washington, DC: Center for American Progress and the Hamilton Project of the Brookings Institution. Available at: http://economics.mit.edu/files/5554

Bachmeier, J.D., Bean, F. D. (2011), Ethnoracial Patterns of Schooling and Work among Adolescents: Implications for Mexican Immigrant Incorporation. "Social Science Research" 40(6): 1579-1595.

Bean, F.D., Brown, S.K., Leach, M.A., Bachmeier, J. D., and Tafoya-Estrada, R. (2012), MexicanAmerican Educational Incorporation: The Size and Meaning of Unauthorized Migration's Legacy. Washington, DC: Institute for the Study of International Migration. 


\section{SM̂PP}

Bean, F.D., Leach, M.A., Brown, S.K., Bachmeier, J. D., and Hipp, J.R. (2011), The Educational Legacy of Unauthorized Migration: Comparisons Across U.S.-Immigrant Groups in How Parents' Status Affects Their Offspring. "International Migration Review" 45(2): 348-385.

Berrol, S.C. (1995), Growing up American: Immigrant Children in America, Then and Now. New York: Twayne.

Crowley, M., Lichter, D.T. and Qian, Z. (2006), Beyond Gateway Cities: Economic Restructuring and Poverty Among Mexican Immigrant Families and Children. "Family Relations" 55(3): 345-360.

Gonzales, R.G. (2011), Learning to Be Illegal Undocumented Youth and Shifting Legal Contexts in the Transition to Adulthood. "American Sociological Review" 76(4): 602-619.

Goździak, E.M. (2014), To Dream or Not to Dream. The Effects of Immigration Status, Discrimination, and Parental Influence on Latino Children's Access to Education. "Migration Studies" 2(3): 392-414.

Hall, M., Greenman, E., Farkas, G. (2010), Legal Status and Wage Disparities for Mexican Immigrants. "Social Forces", 89(2): 491-513.

Haskins, R., Tienda, M. (2011), The Future of Immigrant Children. Policy Brief. Available at: http:// www.brookings.edu/ /media/Files/rc/papers/2011/0420_immigrant_children_haskins/0420_ immigrant_children_haskins.pdf

Holzer, H.J. (2011), Raising Job Quality and Skills for American Workers: Creating More-effective Education and Workforce Development Systems in the States. Washington, DC: The Hamilton Project at the Brookings Institution. Available at: http://www.brookings.edu/research/ papers/2011/11/ workforce-holzer

Martínez, I. (2009), Hispanics See Their Situation in US Deteriorating: Oppose Key Immigration Enforcement Measures. Washington, DC: Pew Hispanic Center. Available at: http://www. pewhispanic.org/files/reports/93.pdf

Massey, D.S. (1987) Do Undocumented Migrants Earn Lower Wages than Legal Immigrants? New Evidence from Mexico. "International Migration Review" 21: 236-274.

Massey, D.S., Durand, J, Malone, N.J. (2003), Beyond Smoke and Mirrors: Mexican Immigration in an Era of Economic Integration. New York, NY: Russell Sage Foundation.

Migration Policy Institute (2010), Senate blocks Passage of Dream Act by Five Votes. Washington, DC. Available at: http://www.migrationinformation.org/Feature/display.cfm?ID=820.

O’Regan, K., Quigley, J. M. (1993) Family Networks and Youth Access to Jobs. "Journal of Urban Economics" 34: 230-48.

Olivas, M.A. (2004) IRIRA, the Dream Act, and Undocumented College Student Residency. Immigration and Nationality Law Review 30 J.C. \& U.L.: 435.

Olivas, M.A. (2011), No Undocumented Child Left Behind: Plyler v Doe and the Education of Undocumented School Children. New York: New York University Press.

Passel, J., Cohn, D’Vera (2011), Unauthorized Immigrant Population: National and State Trends, 2010. Washington, DC: Pew Hispanic Center. Available at: http://www. pewhispanic.org/2011/ 02/01/ unauthorized-immigrant-population-brnational-and-state- trends-2010/

Passel, J., Taylor, P. (2010), Unauthorized Immigrants and Their US-born Children. Washington, DC: Pew Hispanic Center. Available at: http:// pewhispanic.org/\#les/reports/125.pdf

Song, M. (1999), Helping Out: Children's Labor in Ethnic Business. Philadelphia, PA: Temple University Press.

Suárez-Orozco, C., Yoshikawa, H., Teranishi, R.T., \& Suárez-Orozco, M.M. (2011), Growing up in the shadows: The developmental implications of unauthorized status. "Harvard Educational Review", 81(3), 438-472. 